\title{
Significance of Acid Amyloglucosidase in Sulphonylurea-Induced Insulin Release
}

\author{
I. Lundquist \\ Department of Pharmacology, University of Lund, Lund, Sweden \\ Received: March 13, 1974, and in revised form: July 2, 1974
}

\begin{abstract}
Summary. The effect of exogenous acid amyloglucosidase on sulphonylurea-induced insulin release was investigated in mice and rats. 1 . Pretreatment of mice with acid amyloglucosidase enhanced insulin release induced by the different sulphonylurea derivatives, carbutamide, tolbutamide, glibenclamide, and glibornuride. 2. A dose-response relationship between glibenclamide-induced insulin response and amyloglucosidase dosage covering a 64-fold concentration range was established in mice. 3. Pretreatment of the animals with other macromolecules of similar physiological or chemical properties to acid amyloglucosidase such as $\alpha$-amylase, $\beta$-glucuronidase and albumin did not influence glibenclamide-induced insulin release. 4. The effect of acid amyloglucosidase pretreatment on insulin release induced by different agents known to affect the islet-cell adenylate cyclase-cyclic AMP system such as secretin, L-isopropylnoradrenaline (L-IPNA), arginine, glibenclamide and 3isobutyl-1-methylxanthine (IBMX) was tested. It was observed that in animals pretreated with acid amyloglucosidase, insulin release was enhanced when stimulated by glibenclamide, a phosphodiesterase inhibitor, but it
\end{abstract}

was similarly enhanced by arginine, a phosphodiesterase activator. Insulin release induced by secretin, L-IPNA, and IBMX was unaffected. 5. Acid amyloglucosidase pretreatment in rats enhanced plasma immunoreactive insulin levels following glibenclamide injection not only in the peripheral veins but also in the portal vein. 6 . Mice fasted for $24 \mathrm{hrs}$ displayed a markedly depressed insulin response to tolbutamide injection. Pretreatment of the fasted animals with acid amyloglucosidase could restore the tolbutamide-induced insulin release to the sarne level as that recorded in a group of freely fed mice. It is suggested that acid amyloglucosidase plays an important role in insulin secretion induced by sulphonylureas. Most evidence suggests that this effect is exerted within the B-cell although an additional effect on the liver cannot be ruled out.

Key words: Acid amyloglucosidase, insulin release, plasma immunoreactive insulin, sulphonylurea derivatives, $\alpha$-amylase, $\beta$-glucuronidase, albumin, isopropylnoradrenaline, arginine, isobutylmethylxanthine, secretin, mice, rats.
Recent investigations in this laboratory have shown the presence of an exoamylolytic enzyme, acid amyloglucosidase, in isolated islets of the mouse [14, $15,17]$. This hydrolytic enzyme was found to liberate glucose from glycogen, and it was suggested that hydrolysis of B-cell glycogen to glucose through the action of acid amyloglucosidase might be of functional significance for certain insulin releasing processes [14]. Previous studies $[7,8,13]$ had indicated that insulin releasing agents such as glucagon, cyclic- $3^{\prime}, 5^{\prime}$-AMP and sulphonylureas reduce the glycogen levels in mouse pancreatic islets in vitro and that the phosphorolytic glycogenolysis in the islets was comparatively slow [23]. The activity of acid amyloglucosidase in mouse islet tissue, however, was found to be twice that of liver and 10 times that of skeletal muscle. It was markedly reduced to about $10 \%$ of normal in islet tissue from alloxan diabetic mice and more than twice that of the normal level in islets of the insulin hypersecreting obese mouse (AO-Mouse) [17]. It was also shown to display sedimentability, structure-linked latency, and an acid $\mathrm{pH}$-optimum suggesting a lysosomal localization of the enzyme [17]. It was also observed that, compared with control islets, there was an increase in the "free" activity of acid amyloglucosidase in islets prepared from animals two minutes after an intravenous injection of an insulin-releasing dose of the sulphonylurea glibenclamide. Moreover, pretreatment of mice with small amounts of a highly purified acid amyloglucosidase of fungal origin [16] resulted in a marked enhancement of glibenclamide-induced insulin release [18].

The present communication is concerned with further studies of the effect of exogenous amyloglucosidase on sulphonylurea-induced insulin release. The following questions were the main points of interest: 1. Does exogenous amyloglucosidase enhance insulin release stimulated by sulphonylureas other than glibenclamide?

2. Do increasing doses of exogenous amyloglucosidase display a dose-response relation with sulphonylureainduced insulin release?

3. Does pretreatment of mice with enzymes or macromolecules of similar properties or similar chemical nature to amyloglucosidase influence sulphonylurea-induced insulin release?

4. Does acid amyloglucosidase pretreatment affect insulin release induced by agents known to influence the islet-cell adenylate cyclase-cyclic AMP system?

5. Is the observed increase in sulphonylurea-induced insulin release after pretreatment with amyloglucosidase manifested not only in the peripheral veins but also in the portal vein?

6. Does pretreatment of fasting mice with amyloglucosidase improve the normally markedly depressed release of insulin induced by sulphonylurea in this nutritional state? 


\section{Material and Methods}

\section{Animals}

Female mice of the NMRI strain (Laboratory Animal Breeding, Laven, Denmark) weighing 20-30 g and Wistar rats of both sexes (Møllegaard Hansen Avlslaboratorier, Ejby, Denmark) weighing $100-200 \mathrm{~g}$ were used. The animals were kept on a standard pellet diet (Astra-Ewos, Södertälje, Sweden) and tap water ad libitum before and throughout the experiments when not otherwise indicated.

\section{Drugs and Chemicals}

The source of the fungal amyloglucosidase (Aspergillus niger) was "Agidex" (generously supplied by Glaxo Laboratories Ltd., Greenford, England) and subsequently purified as previously described [16]. Tolbutamide and glibenclamide were kindly provided by Boehringer Mannheim GmbH, Germany, carbutamide by Vitrum AB, Stockholm, Sweden, and glibornuride by F. Hoffmann-La Roche AB, Basel, Switzerland. $\beta$ Glucuronidase (beef liver) was obtained from Worthington Biochem. Corp., Freehold, USA, and $\alpha$-amylase (porcine) from British Drug Houses Ltd., Poole, England. Crystalline bovine albumin was from Armour perimental group received acid amyloglucosidase (to mimic the enzyme protein). Blood sampling was performed by orbital puncture using commercial constriction pipettes as described previously [25]. For measurement of insulin concentrations in the portal vein, rats were anaesthetized by the intraperitoneal injection of nembutal, $4 \mathrm{mg} / 100 \mathrm{~g}$ body weight. $250 \mu \mathrm{l}$ blood samples were rapidly taken by puncture of the portal vein $(45 \mathrm{sec})$ or the retrobulbar plexus $(1.5 \mathrm{~min})$ after intravenous injection (tail vein) of glibenclamide or saline, respectively. Blood glucose levels were determined enzymatically [21]. The concentrations of insulin in plasma were determined by the method of Heding [6] using ${ }^{125}$ T-labelled pig insulin and guinea pig anti-piginsulin. Further experimental details will appear under Results. Student's $t$-test was employed for tests of significance.

\section{Results}

Effect of Acid Amyloglucosidase Pretreatment on Insulin Release Induced by Different Sulphonylurea Derivatives

The first series of experiments (Table 1) was designed to elucidate the influence of acid amyloglu-

Table 1. Effect of pretreatment with acid amyloglucosidase $(0.05$ umole $/ \mathrm{kg})$ and gelatine (controls) on insulin release induced by various sulphonylurea compounds. Pretreatment was given $2.5 \mathrm{hrs}$ before the experiment. Blood sampling was performed 2 min following injection of sulphonylureas. Mean and standard error of the mean of $N$ mice. $P=$ probability level of random difference

\begin{tabular}{|c|c|c|c|c|c|c|}
\hline \multirow[t]{2}{*}{$\begin{array}{l}\text { Sulphonylurea } \\
\text { compound }\end{array}$} & \multicolumn{4}{|c|}{$\begin{array}{l}\text { Plasma immunoreactive insulin } \\
\mu \mathrm{U} / \mathrm{ml}\end{array}$} & \multirow[b]{2}{*}{$P$} & \multirow{2}{*}{$\begin{array}{l}\text { Effect of enzyme } \\
\text { pretreatment } \\
\text { percent of controls } \\
\%\end{array}$} \\
\hline & $\overline{\mathrm{N}}$ & $\begin{array}{l}\text { Gela- } \\
\text { tine }\end{array}$ & $\bar{N}$ & $\begin{array}{l}\text { Acid } \\
\text { Amyloglucosidase }\end{array}$ & & \\
\hline $\begin{array}{l}\text { Carbutamide } \\
147 \text { umoles } / \mathrm{kg}^{2}\end{array}$ & 16 & $57 \pm 4$ & 15 & $83 \pm 6$ & $<0.005$ & 147 \\
\hline $\begin{array}{l}\text { Tolbutamide } \\
148 \mu \text { moles } / \mathrm{kg}\end{array}$ & 23 & $62 \pm 4$ & 22 & $81 \pm 5$ & $<0.01$ & 131 \\
\hline $\begin{array}{l}\text { Glibenclamide } \\
0.5 \mu \mathrm{mole} / \mathrm{kg}\end{array}$ & 9 & $49 \pm 4$ & 7 & $83 \pm 5$ & $<0.001$ & 169 \\
\hline $\begin{array}{l}\text { Glibornuride } \\
27 \mu \text { moles } / \mathrm{kg}\end{array}$ & 11 & $48 \pm 5$ & 11 & $89 \pm 8$ & $<0.001$ & 187 \\
\hline
\end{tabular}

Pharmaceut. Comp., Eastbourne, England, and nembutal from Abbott Lab., Chicago, Ill., USA. 3-Isobutyl1-methylxanthine (IBMX) was kindly provided by Searle Co. Ill., USA L-isopropylnoradrenaline (LIPNA) by Hässle AB, Göteborg, Sweden, and pure secretin from GIH, Karolinska Institutet, Stockholm, Sweden. All other drugs and chemicals were obtained from British Drug Houses Ltd., Poole, England.

\section{Experimental}

All compounds used were dissolved in $0.9 \% \mathrm{NaCl}$ and injected into a tail vein of the mouse or rat. Gelatine $(0.05 \%$ gelatine in $0.9 \% \mathrm{NaCl})$ was always given to control animals as pretreatment when the ex- cosidase on the insulin-releasing effect of sulphonylurea derivatives of both the old type (carbutamide, tolbutamide) and the newer type (glibenclamide, glibornuride). Groups of mice were pretreated by intravenous administration of either a small dose $(0.5 \mu \mathrm{mole} /$ $\mathrm{kg}$ ) of purified acid amyloglucosidase or gelatine. $2.5 \mathrm{~h}$ following this pretreatment the animals were injected with a dose of the sulphonylurea derivatives which had been shown to provoke insulin responses of about equal magnitude. From Table 1 it may be seen that amylogiucosidase pretreatment augments the acute insulin release induced by all four sulphonylurea compounds. The increase in insulin response after enzyme pretreatment was $47 \%$ (carbutamide), $31 \%$ (tolbuta- 
mide), $69 \%$ (glibenclamide), and $87 \%$ (glibornuride), respectively, under the present experimental conditions. The newer sulphonylureas were thus slightly more influenced by amyloglucosidase pretreatment than the older ones. Blood glucose concentrations were within the same range in all groups.

Dose-Response Relationship between Dose of Exogenous Amyloglucosidase and Glibenclamide-Induced Insulin Release

In order to establish if a relationship existed between the sulphonylurea-induced insulin response and amyloglucosidase dosage the following experiment was designed. Groups of mice (6 mice in each group) were pretreated with acid amyloglucosidase in doses from 0.0125-0.8 umoles $/ \mathrm{kg}$, covering a 64 -fold concentration range. The animals were then injected with gliben-

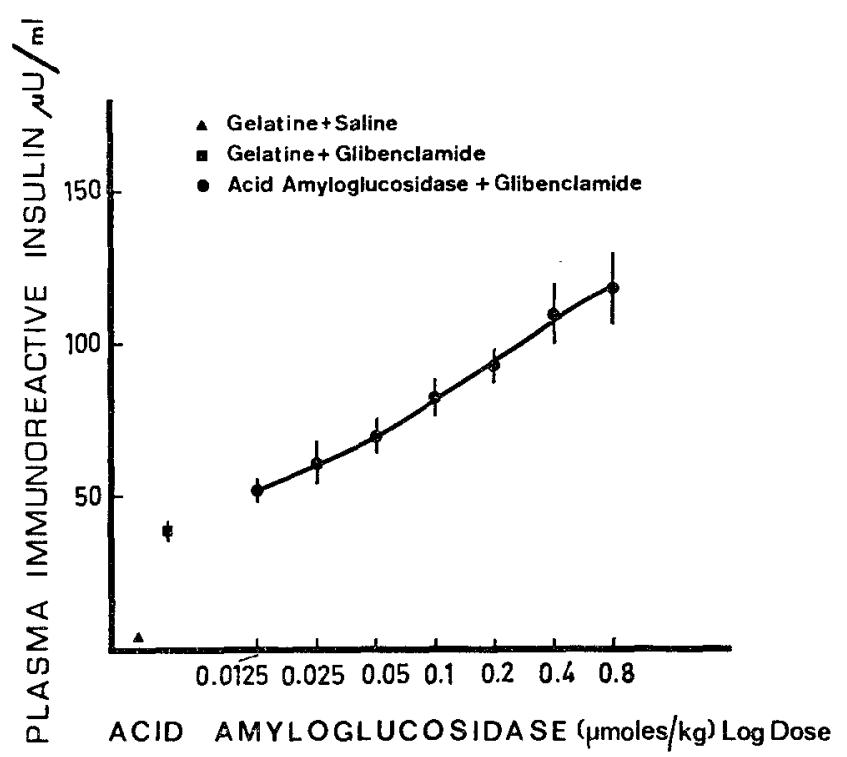

Fig. 1. Dose-response relationship between dose of amyloglucosidase and glibenclamide-induced insulin release. Pretreatment with different doses of acid amyloglucosidase was given 2.5 hrs before the experiment. Plasma insulin levels were measured 2 min after an intravenous injection of glibenclamide $(0.5 \mu \mathrm{mole} / \mathrm{kg})$. Means and standard error of the means are shown. Each group consists of 6 mice. Control groups showing basal insulin levels and insulin levels following gelatine + glibenclamide are included. Abscissa: Dose of acid amyloglucosidase, ( $\mu$ moles/kg body weight) (log scale) Ordinate: Plasma immunoreactive insulin, $\mu \mathrm{U} / \mathrm{ml}$. Blood glucose levels were within the same range in all groups

clamide $(0.5 \mu \mathrm{moles} / \mathrm{kg})$ and acutely released insulin (peak levels) was determined. Appropriate groups of animals for recording of plasma insulin levels in glibenclamide-controls and saline-controls were included (Fig. 1). It appears from Fig. 1 that increasing doses of acid amyloglucosidase resulted in increasing peak levels of insulin following glibenclamide injection in an ordinary log dose-response relationship.
Effect of Other Macromolecules of Similar Physiological or Chemical Properties as Acid Amyloglucosidase on Glibenclamide-Induced Insulin Release

A series of experiments was designed to test whether other macromolecules of the same enzymatic or chemical nature as acid amyloglucosidase might influence sulphonylurea-induced insulin release. The following macromolecules were selected: Albumin because it has similar molecular weight and charge to the protein part of the acid amyloglucosidase; $\beta$-Glucuronidase because it is a lysosomal hydrolase of glycoprotein nature, as is the acid amyloglucosidase; and $\alpha$-amylase because it is a glycogenolytic hydrolase of glycoprotein nature, producing mainly maltose as reaction product instead of the free glucose produced by acid amyloglucosidase. The result is presented in Table 2 . Table 2 shows that only acid amyloglucosidase

Table 2. Effect of pretreatment with different macromolecules of similar chemical or enzymatic properties as acid amyloglucosidase on glibenclamide-induced insulin release in mice. Mean and standard error of mean of $N$ mice. $P=$ probability level of random difference. $N S=$ not significant. Acid amyloglucosidase (0.05 umoles $/ \mathrm{kg}$ ) and other macromolecules (in a dose on weight basis equivalent to 0.05 pmoles/kg of acid amyloglucosidase) were given by intravenous injection 2.5 hrs prior to the experiment. Blood sampling was performed 2 min following the injection of glibenclamide $(0.5$ umole (kg)

\begin{tabular}{lrcl}
\hline Pretreatment & N & $\begin{array}{l}\text { Plasma } \\
\text { Immunoreactive } \\
\text { Insulin } \mu \mathrm{U} / \mathrm{ml}\end{array}$ & $P$ \\
\hline Gelatine (controls) & 14 & $92 \pm 7$ & - \\
Albumin & 12 & $73 \pm 10$ & $\mathrm{NS}$ \\
$\beta$-Glucuronidase & 8 & $105 \pm 11$ & $\mathrm{NS}$ \\
$\alpha$-Amylase & 6 & $100 \pm 8$ & $\mathrm{NS}$ \\
Acid Amyloglucosidase & 19 & $169 \pm 14$ & $<0.001$ \\
\hline
\end{tabular}

has the ability to enhance glibenclamide-induced insulin release, while the other macromolecules were without any effect.

Influence of Acid Amyloglucosidase Pretreatment on Insulin Release Induced by Agents Known to Affect the Adenylate Cyclase-Cyclic AMP System

Sulphonylurea compounds have been shown to affect the adenylate cyclase-cyclic AMP system in different tissues including the islet cells, suggesting an involvement of this system in sulphonylurea-induced insulin release (cf. 26). Therefore it was decided to test the effect of acid amyloglucosidase pretreatment on insulin release induced by different agents known to affect the islet-cell adenylate cyclase-cyclic $A M P$ system. It appears from Table 3 that the adenylate cyclase activators secretin and L-IPNA are unaffected by acid amyloglucosidase. Insulin release induced by a phosphodiesterase activator, arginine, and a phosphodiesterase inhibitor, glibenclamide, is significantly 
augmented by the enzyme, whereas another phosphodiesterase inhibitor, the very potent IBMX, is unaffected.

Effect of Acid Amyloglucosidase Pretreatment on Glibenclamide-Induced Insulin Release in the Portal and Peripheral Vein of the Rat

The next series of experiments was designed to elucidate whether acid amyloglucosidase pretreatment would enhance plasma insulin levels following sulphonylurea injection not only in the peripheral veins but also in the portal vein. Anaesthetized rats were laparotomized and an intravenous injection of glibenclamide was given via a tail vein. After about 45 sec a 250 ul blood sample was drawn from the portal vein. Blood samples from peripheral veins were drawn from the retrobulbar vein plexus after about $1.5 \mathrm{~min}$. It is evident from Fig. 2 that the acid amyloglucosidaseinduced increase in peripheral plasma insulin levels presented in Fig. 3. Groups of both fasted and fed mice were pretreated with acid amyloglucosidase (stippled columns). Controls received gelatine (white columns). It appears that tolbutamide-induced insulin release in fasted mice is markedly reduced compared with the response in fed animals. It is also shown (Fig. 3) that pretreatment with acid amyloglucosidase in fasted mice restores the insulin response to tolbutamide to the normal level recorded in the gelatine-pretreated fed mice. Acid amyloglucosidase pretreatment in the fed animals enhanced tolbutamide-induced insulin release, as was expected (Fig. 3).

\section{Discussion}

In a recent investigation [16] it was demonstrated that injection of small amounts of rigorously purified acid amyloglucosidase into normal mice induced a

Table 3. Effect of acid amyloglucosidase pretreatment on insulin release induced by various agents known to affect the activities of islet-cell adenylate cyclase or cyclic $A M P$ phosphodiesterase. Peak levels of plasma immunoreactive insulin levels were recorded after intravenous injection of the compounds. Pretreatment with acid amyloglucosidase $(0.05 \mu$ mole $/ \mathrm{kg}$ ) or gelatine (controls) was given $2.5 \mathrm{hrs}$ before the experiment. Mean and standard error of the mean of $N$ mice. $P=$ probability level of random difference. NS $=$ not significant

\begin{tabular}{|c|c|c|c|c|c|}
\hline \multirow[t]{2}{*}{$\begin{array}{l}\text { Insulin-roleasing } \\
\text { agent }\end{array}$} & \multicolumn{4}{|c|}{$\begin{array}{l}\text { Plasma Immunoreactive Insulin } \\
\mu \mathrm{U} / \mathrm{ml}\end{array}$} & \multirow[b]{2}{*}{$P$} \\
\hline & $\overline{\mathrm{N}}$ & Gelatine & $\mathrm{N}$ & $\begin{array}{l}\text { Acid } \\
\text { Amyloglucosidase }\end{array}$ & \\
\hline $\begin{array}{l}\text { Secretin } \\
100 \mathrm{U} / \mathrm{kg}\end{array}$ & 9 & $71 \pm 12$ & 9 & $77 \pm 10$ & NS \\
\hline $\begin{array}{l}\text { L-IPNA } \\
0.69 \mu \mathrm{mole} / \mathrm{kg}\end{array}$ & 9 & $98 \pm 9$ & 9 & $108 \pm 13$ & NS \\
\hline $\begin{array}{l}\text { Arginine } \\
0.95 \mathrm{mmole} / \mathrm{kg}\end{array}$ & 15 & $65 \pm 7$ & 15 & $117 \pm 11$ & $<0.001$ \\
\hline $\begin{array}{l}\text { Glibenclamide } \\
0.5 \mu \mathrm{mole} / \mathrm{kg}\end{array}$ & 12 & $86 \pm 6$ & 11 & $132 \pm 8$ & $<0.001$ \\
\hline $\begin{array}{l}\text { IBMX } \\
42 \mu \mathrm{moles} / \mathrm{kg}\end{array}$ & 9 & $53 \pm 8$ & 8 & $60 \pm 9$ & NS \\
\hline
\end{tabular}

following glibenclamide injection was manifested also in the portal vein. A slight decrease in portal blood glucose level after acid amyloglucosidase pretreatment was also observed (Fig. 2).

Comparison of Sulphonylurea-Induced Insulin Release with and without Acid Amyloglucosidase Pretreatment in Fed and Fasted Mice, Respectively

Since fasting is known to reduce sulphonylureainduced insulin release it was decided to study the influence of acid amyloglucosidase pretreatment on tolbutamide-induced insulin release in the fasting state. Accordingly mice were fasted for $24 \mathrm{~h}$ before the experiment. A control group receiving the standard pellet diet was included for comparison. All animals were given tap water ad libitum. The pattern of tolbutamideinduced insulin response in the different groups is small but significant elevation of basal plasma insulin levels. The most striking effect of treatment of normal mice with the purified enzyme, however, was a marked enhancement of insulin release in these mice following an intravenous injection of the sulphonylurea-derivative, glibenclamide [18]. From the data presented above it is obvious that this augmentation of glibenclamideinduced insulin release is shared by other sulphonylurea-derivatives. It is demonstrated (Table 1) that acid amyloglucosidase pretreatment increases insulin release induced by sulphonylureas of both the old generation (carbutamide, tolbutamide) and the new (glibenclamide, glibornuride). The increase in insulin response following amyloglucosidase pretreatment was more pronounced after injection of the newer sulphonylureas (glibenclamide 69\%, glibornuride 87\%) than after the older ones (carbutamide $47 \%$, tolbutamide $31 \%$ ). 
Whether these results reflect a qualitative or a quantitative difference between the new and the old type of sulphonylurea-derivatives cannot be answered at present.

Further evidence for the dependency of sulphonylurea-induced insulin release on acid amyloglucosidase activity is the observation that an ordinary log doseresponse relationship could be established between amyloglucosidase dosage and glibenclamide-induced

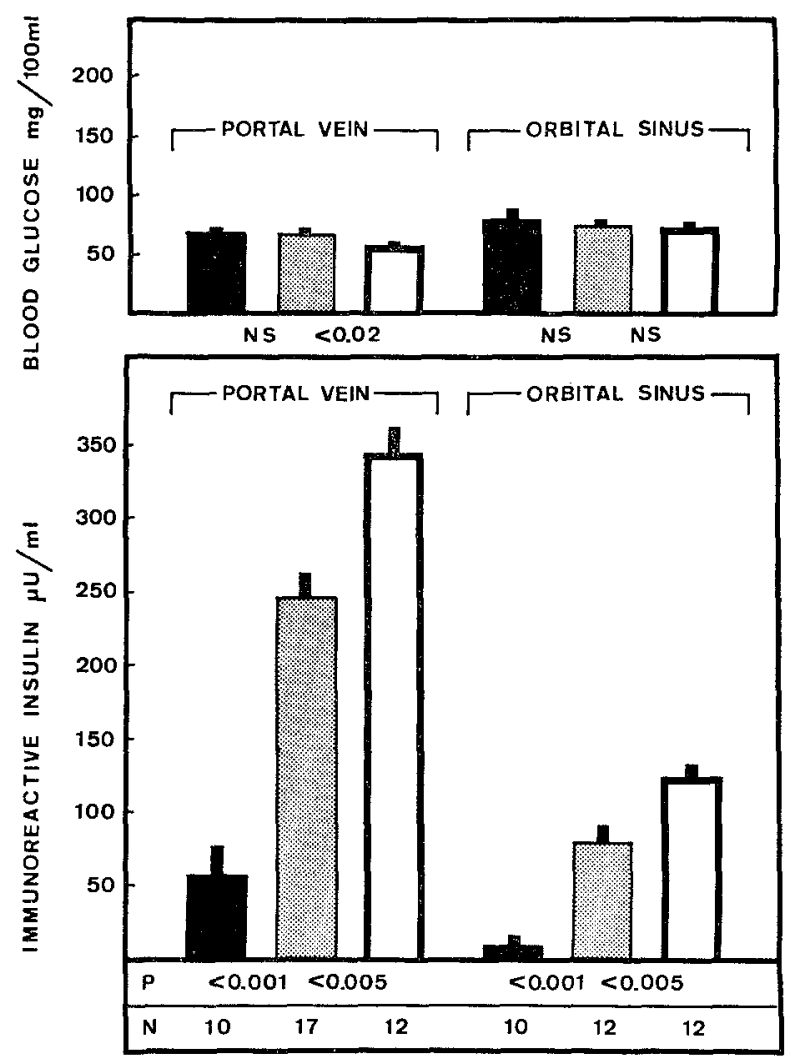

Fig. 2. Blood glucose and plasma immunoreactive insulin levols in portal and orbital veins following the intravenous injection of gelatine +-saline (black columns), gelatine + glibenclamide (stippled columns) and acid amyloglucosidase + glibenclamide (white columns) in anaesthetized rats. Gelatine or acid amyloglucosidase $(0.0125 \mu \mathrm{mole} / \mathrm{rat})$ was given $2.5 \mathrm{hrs}$ before the experiment. Blood samples were drawn eithor $45 \mathrm{sec}$. (portal vein) or $1.5 \mathrm{~min}$ (orbital sinus) following injection of saline or glibenclamide $\mathbf{0 . 2}$ $\mu \mathrm{mole} / \mathrm{rat})$. Bars indicate standard error of the mean. $P=$ probability level of random difference. $\mathrm{N}=$ number of rats. $\mathrm{NS}=$ not significant

insulin release (Fig. 1). This dose-response curve covered a 64-fold concentration range, with the lower limit at a dose of only $0.0125 \mu$ mole amyloglucosidase $/ \mathrm{kg}$ body weight. Whether this influence of exogenous acid amyloglucosidase activity on sulphonylurea-induced insulin release is exerted only within the B-cell, as has been hypothesized on mainly indirect evidence [14, 18], is still not definitely proven. For example, the possibility existed that other macromolecules of physiolo- gical and chemical properties similar to acid amyloglucosidase might influence sulphonylurea-induced insulin release. In this investigation a couple of macromolecules with such properties were tested. The molecular weight of Aspergillus niger amyloglucosidase is about 100000 [24]. It is a glycoenzyme and its protein part has similar molecular weight and charge to albumin. Administration of albumin to mice, however, did not influence sulphonylurea-induced insulin release.

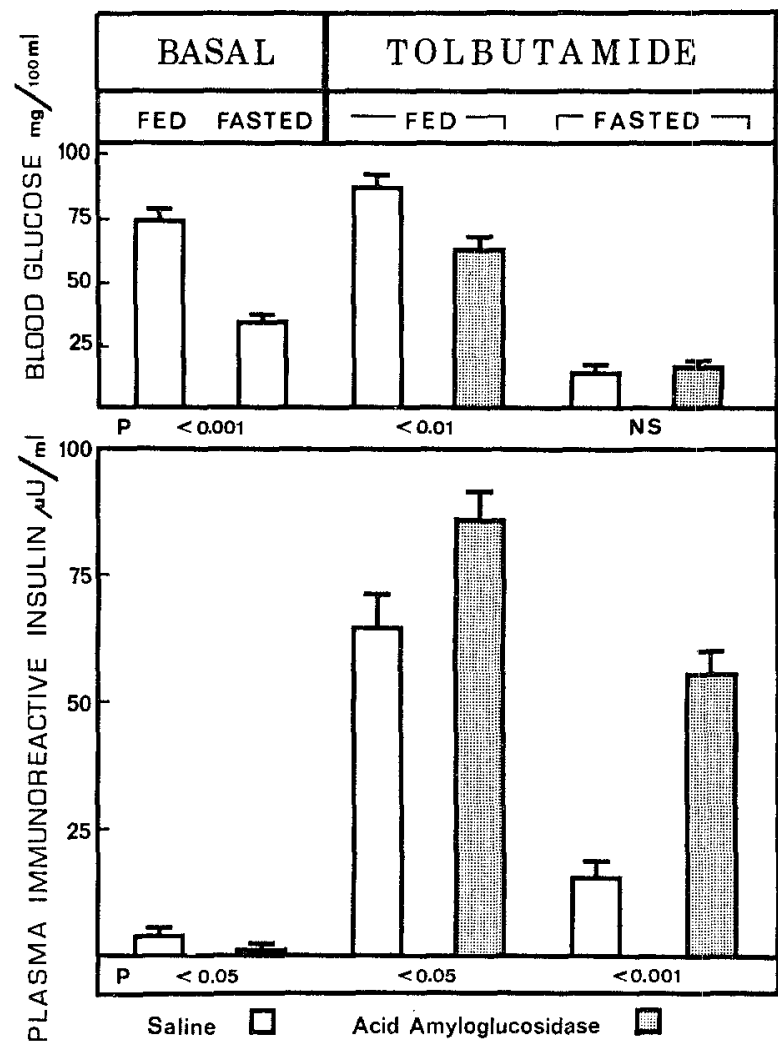

Fig. 3. Effect of acid amyloglucosidase pretreatment on tolbutamide-induced insulin release in fed and fasted mice, respectively. Blood glucose and plasma immunoreactive insulin levels in groups of mice treated with gelatine + saline and gelatine + tolbutamide (white columns) or acid amyloglucosidase + tolbutamide (stippled columns). Gelatine or acid amyloglucosidase $(0.05 \mathrm{\mu mole} /$ $\mathrm{kg}$ ) was given $2.5 \mathrm{hrs}$ prior to the experiment. Blood samples were drawn $2 \mathrm{~min}$ following injection of saline or tolbutamide (148 $\mathrm{kmoles} / \mathrm{kg})$. Bars indicate standard error of the mean. $P=$ probability level of random difference. $\mathrm{NS}=$ not significant. $6-8$ mice in each group

Similarly, $\beta$-glucuronidase, a glycoenzyme of lysosomal origin, was without effect (Table 2). Another glycoenzyme with glycogenolytic properties, $\alpha$-amylase, was also found not to affect sulphonylurea-induced insulin release, at least not in doses in the range of $\mathbf{E D}_{50}$ of amyloglucosidase. The failure of $\alpha$-amylase to influence insulin release is further evidence for the specificity of amyloglucosidase action in this respect, since although $\alpha$-amylase induces a hydrolytic gly- 
cogenolysis in a way similar to amyloglucosidase, the reaction product is mainly maltose instead of glucose. Furthermore, $\alpha$-amylase has the ability to penetrate into cells and has been shown to reduce liver glycogen levels after administration in vivo [12] as has amyloglucosidase [16].

Reduction of the total carbohydrate level of the body after a fasting period of $24 \mathrm{~h}$ did not inhibit or reduce amyloglucosidase enhancement of tolbutamideinduced insulin release (Fig. 3). On the contrary after enzyme pretreatment there was a restoration of the decreased insulin response to tolbutamide induced by fasting. This was rather unexpected and raises the question whether islet amyloglucosidase levels are sensitive to changes in the nutritional condition of the animals. Such studies are now under way.

A further contribution to the view that a major effect of exogenous amyloglucosidase is exerted in the B-cell is the observation (Fig. 2) that glibenclamideinduced elevation of plasma insulin levels in rats is markedly enhanced not only in the peripheral circulation but also in the portal vein after pretreatment with amyloglucosidase. It also shows that this effect of amyloglucosidase is not species dependent so far. An effect of amyloglucosidase on plasma insulin levels elicited through an action in the liver cannot, however, be ruled out because recent data (unpublished) show that a major part of the injected enzyme is trapped by the liver, an organ which is known to have a profound influence on the fate of secreted insulin. Furthermore, there is evidence for an extrapancreatic action of sulphonylureas manifested in the liver $[22,26]$. However, because the insulinogenic effect of arginine (Table 3) is enhanced by amyloglucosidase pretreatment, this again favours a major action of the enzyme in the B-cell, since there is no evidence of an effect of amino acids on insulin trapping in the liver.

Recent studies have shown that sulphonylureas affect the adenylate cyclase-cyclic AMP system in differerent tissues, including the islet cells, where they have been shown to act as phosphodiesterase inhibitors $[2,26,27]$. Therefore, I tested the possibility that amyloglucosidase pretreatment would enhance insulin release induced by different insulin stimulators known to affect the islet-cell adenylate cyclase-cyclic AMP system. The data in Table 3 above shows that enzyme pretreatment did not influence insulin release induced. by L-IPNA and secretin, compounds which raise the intracellular cyclic AMP levels through stimulation of adenylate cyclase, and IBMX, which raises cyclic AMP through phosphodiesterase inhibition. Insulin release following a phosphodiesterase activator, arginine [27], was significantly enhanced by amyloglucosidase pretreatment. These data show that acid amyloglucosidase pretreatment does not enhance sulphonylurea-induced insulin release through an action on the adenylate cyclase-cyclic AMP system, suggesting that the lysosome-amyloglucosidase pathway so far operates indepedently of cyclic AMP. On the other hand, there is hitherto no evidence against the possibility that sulphonylureas might have a dual insulinogenic action on the B-cell, which, in addition to possible extrapancreatic actions, would tentatively explain the unique and beneficial effects of these agents on maturity onset diabetics with functioning B-cells.

An important question for the presumed validity of the above in vivo results is, of course, the question whether enzyme pretreatment might affect insulin release in response to sulphonylureas indirectly. Although the in vivo situation never can be fully mimicked in vitro, experiments are currently under way to study various effects of amyloglucosidase pretreatment on isolated islets in vitro. However, there seems to be no likely candidate among the known physiological insulin secretagogues, which, activated by amyloglucosidase pretreatment, might be responsible for an enhanced insulin releasing effect by sulphonylureas within $45 \mathrm{sec}$ (Fig. 2) or after a fasting period of $24 \mathrm{~h}$ (Fig. 3). Further indirect evidence for amyloglucosidase participation in sulphonylurea-induced insulin release is the previously reported observation [18] that the "free" activity of endogenous amyloglucosidase is enhanced in islets prepared from animals two minutes after an intravenous injection of glibenclamide. Although this increase might be a consequence rather than a cause of the enhanced insulin release other observations, such as a marked enhancement of total endogenous acid amyloglucosidase activity in the islets of the insulin hypersecreting obese mouse (AOmouse) [17] and an insulin releasing capacity in three different strains of mice following a maximal dose of glibenclamide, which roughly correlated with islet amyloglucosidase activity (unpublished), would still favour a role for the enzyme in stimulated insulin secretion. Furthermore previous investigations [18] have shown an increase of glibenclamide-induced insulin release following a lysosomal "labilizer" (progesterone), and a depression following a lysosomal "stabilizer" (dexamethasone). These steroids also act upon nuclear metabolism and other membrane systems and enzyme activities, but other types of lysosome "stabilizers" such as sodium salicylate have recently been shown to depress glibenclamide-induced insulin secretion, while no effect on IPNA-induced insulin release was observed (unpublished).

The nature of the process which constitutes the proposed link between the injected sulphonylurea and the activation of the acid amyloglucosidase in the Bcell and the exact mode of action of the enzyme are still pertinent questions which remain to be elucidated. The sulphonylurea might, for example, penetrate the B-cell membrane, directly activate the lysosome and liberate latent enzyme activity or, alternatively, trigger a receptor on the cell membrane which in turn transmits a signal (messenger) to the lysosome. Recent in vitro investigations by Hellman and coworkers [9, $10,11]$ suggest that the sulphonylureas do not readily penetrate the pancreatic B-cells, but more probably 
stimulate insulin release by a direct action on the Bcell plasma membrane. These results thus favour the latter alternative. The possibility also exists that the injected enzyme might act directly to modify the Bcell plasma membrane, which has been shown recently in vitro for other types of hydrolytic glycosidases [20]. However, such an effect seems highly unlikely with our present knowledge, since the acid amyloglucosidase acts primarily on $\alpha-1,4$-glucosidic linkages and it hydrolyzes other glucosidic bonds at a comparatively negligible rate $[1,24]$. Moreover, glucose polymers such as glycogen are the substrate of choice and maltose and other short-chained $\alpha-1,4$-oligoglucosides are hydrolyzed considerably more slowly $[1,19]$, which, theoretically, should be the case also for any possible amyloglucosidase-susceptible, $\alpha-1,4$-glucosidic linkages in, for example, membrane glycoproteins.

So far a great deal of indirect evidence obtained seems to be compatible with the above hypothesis that the major action of the sulphonylureas to release insulin is exerted through the hydrolytic production of glucose from the B-cell glycogen by the action of acid amyloglucosidase. The liberated glucose is then expected to act on the hypothetical "glucoreceptor" to elicit insulin release. It is known that sulphonylureainduced insulin release is somewhat more rapid in onset than is glucose-induced insulin release $[4,5]$, although the contrary might be expected. However, as long as we do not know the exact nature, significance and localization of the hypothetical "glucoreceptor" this discrepancy might well be explained by compartmentalization. This might also explain the apparent failure of mannoheptulose to inhibit sulphonylurea-induced insulin release, although mannoheptulose is an inhibitor of the response to glucose [3].

From the data presented and discussed above it is suggested that the major part of the acutely released insulin following an intravenous injection of sulphonylurea is released through a direct action on the B-cell involving the lysosome-amyloglucosidase system. Whether the sulphonylurea triggers a receptor on the cell membrane, which in turn transmits a signal to the lysosome, or exerts its action direct on the lysosome remains to be elucidated.

Acknowledgements. The skilful technical assistance of Mrs. Lena Kvist and Mrs. Inger Relke is gratefully acknowledged. This work was supported by the Swedish Medical Research Council (Projeot No. K73-04X-4142-01 and B74-04X-4286-01) and "Jubileumsfonden" (Ferrosan, Malmö, Sweden).

\section{References}

1. Abdullah, M., Fleming, I.D., Taylor, P.M., Whelan, W.J.: Substrate specificity of the amyloglucosidase of Aspergillus niger. Biochem. J. 89, 35 P-36P (1963)

2. Ashcroft, S.J.H., Randle, P.J., Täljedal, I.-B.: Cyclic nucleotide phosphodiesterase activity in normal mouse pancreatic islets. FEBS Letters 20, 263-266 (1972)
3. Coore, H.G., Randle, P.J.: Regulation of insulin secretion studied with pieces of rabbit pancreas incubated in vitro. Biochem. J. 93, 66-78 (1964)

4. Curry, D.L.: Is there a common beta cell insulin compartment stimulated by glucose and tolbutamide? Amer. J. Physiol. 220, $319-323$ (1971)

5. Grodsky, G.M., Lee, J., Fanska, R., Smith, D.: Insulin secretion from the in vitro perfused pancreas of the rat: Effect of Ro-4563 and other sulfonylureas. In: Recent hypoglycemic sulfonylureas. Mechanisms of action and clinical indications, Ed. by U.C. Dubach and A. Bückert, pp. 83-94. Bern: Hans Huber Publishers 1971

6. Heding, L.: A simplified insulin radioimmunoassay method. In: Donato, L. et at. (eds.): Labelled proteins in tracer studies, pp. $345-350$. Brussels: Euratom 1966

7. Hellman, B., Idahl, L.-A.: On the functional significance of the pancreatic $\beta$-cell glycogen. In: The structure and metabolism of the pancreatic islets, Ed. by S. Falkmer et al., p. 253. Oxford: Pergamon Press 1970

8. Hellman, B., Lernmark, A.: A possible role of the pancreatic $\alpha_{1}$ and $\alpha_{2}$-cells as local regulators of insulin secretion $i n$ : The structure and metabolism of the pancreatic islets, Ed. by S. Falkmer et al., p. 453. Oxford: Pergamon Press 1970

9. Hellman, B., Lernmark, A., Sehlin, J., Täljedal, I.-B.: The pancreatic $\beta$-cell recognition of insulin secretagogues. Inhibitory effects of a membrane probe on the islet uptake and insulin-releasing action of glibenclamide. FEBS Letters 34, 347-349 (1973)

10. Hellman, B., Sehlin, J., Täljedal, I.-B.: The pancreatic $\beta$-cell recognition of insulin secretagogues: II. Site of action of tolbutamide. Biochem. biophys. Res. Commun. 45, 1384-1388 (1971)

11. Hellman, B., Sehlin, J., Täljedal, I.-B.: The pancreatic $\beta$-cell recognition of insulin secretagogues IV. Islet uptake of sulfonylureas. Diabetologia 9, 210-216 (1973)

12. Hiatt, N.: Blood glucose and liver glycogen following intravenous injection of amylase. Proc. Soc. exp. Biol. (N.Y.) 119, 667-670 (1965)

13. Idahl, L.-Å., Hellman, B.: Regulation of pancreatic $\beta$-cell glycogen through cyclic-3,5-AMP. Diabetologia 7, 139-142 (1971)

14. Lundquist, I.: Insulin secretion. Its regulation by monoamines and acid amyloglucosidase. Acta physiol. scand. Suppl. 372, 1-47 (1971a)

15. Lundquist, I.: Method for determination of acid amyloglucosidase in isolated islets of the pancreas. Enzyme 12, 647-657 (1971b)

16. Lundquist, I.: Acid amyloglucosidase and carbohydrate regulation. I. Effect of exogenous amyloglucosidase on tissue glycogen, blood glucose, and plasma insulin. Horm. Metabol. Res. 4, 151-158 (1972a)

17. Lundquist, I.: Acid amyloglucosidase and carbohydrate regulation. II. Acid amyloglucosidase activity in the endocrine pancreas. Horm. Metabol. Res. 4, $245-249$ (1972b)

18. Lundquist, I.: Acid amyloglucosidase and carbohydrate regulation. III. The induction of sulphonylurea-stimulated insulin release and its dependence on intracellular monoamines. Horm. Motabol. Res. 4, $341-348(1972 \mathrm{c})$

19. Lundquist, I., Lindstrand, K., Rerup, C.: Separation and characterization of a glycogenolytic enzyme from a glucose oxidase preparation obtained from Asper- 
gillus niger. Scand. J. clin. Lab. Invest. 23, 89-95 (1969)

20. Maier, V., Schatz, H., Hinz, M., Pfeiffer, E.F., Blessing, J.: Biosynthesis and secretion of insulin after treatment of pancreatic islets of mice with several glycosidases. Endokrinologie 62, 269-278 (1973)

21. Marks, V.: An improved glucose oxidase method for determining blood, C.S.F. and urine glucose levels. Clin. chim. Acta 4, 395-401 (1959)

22. Marshall, A., Gingerich, R.L., Wright, P.H.: Hepatic effect of sulfonylureas. Metabolism 19, 1046-1052 (1970)

23. Matschinsky, F.M., Ellerman, J.E.: Metabolism of glucose in the islets of Langerhans. J. biol. Chem. 243, $2730-2736$ (1968)

24. Pazur, J.H., Kleppe, K.: The hydrolysis of $\alpha-D$. glucosides by anyloglucosidase from Aspergillus niger. J. biol. Chem. 237, 1002-1006 (1962)

25. Rerup, C., Lundquist, I.: Blood glucose level in mice. I. Evaluation of a new technique of multiple serial sampling. Acta endocr. (Kbh.) 52, 357-367 (1966)

26. Roth, J., Prout, T.E., Goldfine, I. D., Wolfe, S.M., Muenzer, J., Grauer, L.E., Mareus, M.L.: Sulfonylureas: Effects in vivo and in vitro. Ann. intern. Med. $75,607-621(1971)$

27. Sams, D.J., Montague, W.: The role of adenosine $3^{\prime}: 5^{\prime}$-cyclic monophosphate in the regulation of insulin release. Biochem. J. 129, 945-952 (1972)

Dr. I. Lundquist

Department of Pharmacology

Sölvegatan 10

S-22362 Lund,

Sweden 